\title{
SISTEM PENDUKUNG KEPUTUSAN DALAM PENERIMAAN CALON ANGGOTA SECURITY PADA PT. NAGA HARI UTAMA DENGAN METODE MULTI OBJECTIVE OPTIMIZATION ON THE BASIS OF RASIO ANALYSIS (MOORA)
}

\author{
Decision Support System in Acceptance of Security Members in PT. Dragon Main Day With Multi \\ Objective Optimization Method on The Basis of Ratio Analysis (Moora) \\ Soka Wardiman Sinaga ${ }^{1}$, Fitriana Harahap ${ }^{2}$ \\ ${ }^{1,2}$ Program Studi Sistem Informasi, Fakultas Teknik dan Ilmu Komputer \\ Universitas Potensi Utama, Jl.K.L. Yos Sudarso KM 6.5 Tanjung Mulia-Medan \\ E-mail:wardimansoka@gmail.com ${ }^{1}$,fitrianaharahap1@gmail.com ${ }^{2}$
}

\begin{abstract}
ABSTRAK
Security Merupakan aparat keamanan yang bertugas di salah satu instansi/perusahaan yang pada dasarnya merupakan suatu bentuk pengamanan yang bertugas membantu Polri dibidang penyelengaraan kemanan dan ketertiban masyarakat, yang terbatas pada lingkungan kerjanya. Dengan melihat begitu pentingnya kemanan yang saat ini banyak sekali di butuhkan maka sebagai perusahaan yang bergerak di bidang penyalur dan penyedia jasa security PT. Naga Hari Utama harus senantiasa menyediakan calon anggota security yang berkopeten di bidangnya. Untuk mendapatkan kemudahan dalam menyeleksi calon anggota security maka dengan adanya sistem komputer yang saat ini berkembang penerapan sistem penunjang keputusan merupakan solusi yang dapat membantu proses pengambilan keputusan pada anggota security. Dengan menerapkan metode MOORA dalam pengambilan keputusan penerimaan calon anggota security adalah solusi yang membantu dalam proses pengambilan keputusan, dengan menggunakan pemograman Visual basic dan database SQL Server dalam penerapan pemograman yang di bagung maka akan memudahakan dalam pengambilan keputusan.
\end{abstract}

Kata Kunci : Security, Sistem Penunjang Keputusan, MOORA, Visual Basic, SQL Server.

\section{ABSTRACT}

Security Is a security apparatus assigned to an agency/company which is basically a form of security that is tasked with assisting the Police in the administration of security and public order, which is limited to their work environment. By seeing the importance of security which is currently in need of a lot, as a company engaged in the distributor and provider of security services, PT. Naga Hari Utama must always provide prospective security members who are competent in their fields. To get it easier in selecting prospective security members, with the existence of a computer system that is currently developing the application of a decision support system is a solution that can help the decision-making process of security members. By applying the MOORA method in decision making for recruiting prospective members of security is a solution that helps in the decision making process, using Visual Basic programming and SQL Server databases in the application of the bagged baggage it will facilitate decision making.

Keywords: Expert System, Hemorrhoids, PHP, Mysql. 


\section{PENDAHULUAN}

Security Merupakan salah satu aparat keamanan yang bertugas di salah satu instansi/perusahaan pada dasarnya merupakan suatu bentuk pengamanan yang bertugas membantu Polri dibidang penyelengaraan kemanan dan ketertiban masyarakat, terbatas pada lingkungan kerjanya. [1].

Oleh sebab itu banyak nya kebutuhan akan permintaan security,diperlukan suatu system yaitu Sistem Pendukung Keputusan sistem yang berguna untuk membantu para pengambil keputusan semi terstruktur dengan mengunakan perhitungan yang susuai tanpa mengantikan pengambil keputusan. [2].

Dengan penerapan metode Metode Multi Objective Optimization on the basis of rasio analysis (MOORA) sebuah metode yang Multiobjektif yaitu mengobtimalkan dua atau lebih atribut yang saling bertentangan secara bersamaan.[3] yang dikembangkan oleh Brauers dan Zavadkas pada tahun 2006. [4] akan membantu proses penerimaan yang mana suatu cara untuk mendapatkan calon anggota tenaga kerja yang berkualitas dan mampu bekerja sesuai dengan kemampuan masing masing di lingkungan kerja nya [5]. PT.Naga Hari Utama yang merupakan salah satu penyalur dan penyedia tenaga kerja security, maka pemilihan calon anggota security yang tepat, cepat, sesuai dengan kriteria dan dapat bekerja sesuai dengan kemampuan masing masing adalah tugas utama PT.Naga Hari Utama.

\section{METODE PENELITIAN}

Metodologi penelitian merupakan langkah langkah dalam proses pemecahan suatu masalah yang akan di selesaikan.[6] langkah penelitian menggunakan metode waterfall. Metode waterfall adalah model dalam pengembangan sistem informasi yang sistematik dan sekuensial [7].

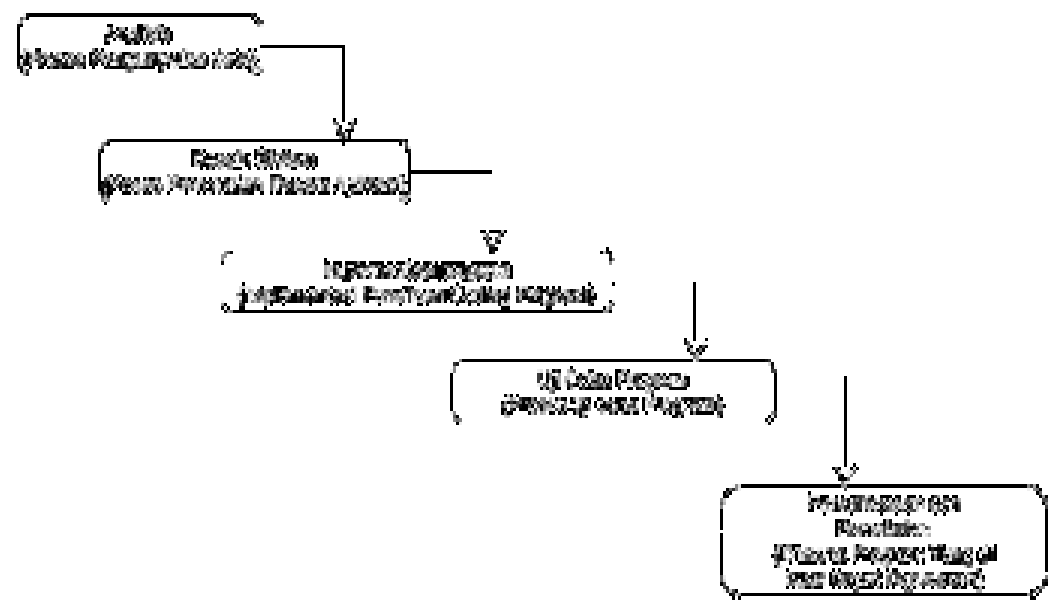

Gambar 1. Waterfall Diagram

Kegiatan yang dilakukan dalam tiap-tiap tahap model waterfall adalah sebagai berikut :

1. Pengumpukan Data

Merupakan Data yang dibutuhkan dalam melakukan perancangan sistem adalah Data calon anggota security.[8] Kegiatan yang dilakukan dalam tiap-tiap tahap model waterfall adalah sebagai berikut :

a. Pengamatan (Observasi)

Penulis melakukan pengamatan langsung ke PT.Naga Hari Utama untuk Mendapatkan data bagaimana cara proses penyeleksian anggota calon security.

b. Wawancara (Interview)

Dalam wawancara ini penulis langsung menemui sumber informasi dan mengajukan pertanyaan yang berhubungan dengan objek penelitian kepada PT.Naga Hari Utama Ibu Martyna M. Sitanggang Dimana isi dari wawancara tersebut ialah :

1) Bagaimana sistem penerimaan calon anggota security yang berjalan saat ini? 
2) Bagaimana memproses data calon security agar dapat bergabung di PT. Naga Hari Utama?

2. Desain Sistem

3) Apakah Kriteria dan penilaian bagi calon anggota security di PT. Naga Hari Utama?

Analysis Desain Sistem Dalam tahap ini penulis menggambarkan dan mepersiapkan software yang akan dikembangkan dari bentuk maupun model yang akan dibuat sehingga mempermudah user.

3. Implementasi Program

Dalam tahap ini penulis melakukan pembuatan dan pengerjaan terhadap software berdasarkan yang telah penulis desain

4. Uji Coba Program

Dalam tahap ini penulis melakukan percobaan terhadap software yang telah di implementatsikan dan melakukan perbaikan bila muncul kesalahan dalam pemakaian dengan menggunakan blackbox.

5. Pemiliharaan dan Pemakaian

Dalam tahap ini penulis melakukan pemeliharaan dalam pemakaian langsung sehingga dapat mengatasi kesalahan yang muncul.

\section{HASIL DAN PEMBAHASAN}

Analisis sistem dilakukan guna untuk mengetahui gambaran umum sistem yang sedang berjalan tentang proses pengambilan keputusan penerimaan calon anggota security pada PT. Naga Hari Utama.

Kesulitan pihak PT. Naga Hari Utama dalam menetukan calon anggota security yang cepat dan tepat sesuai dengan permintaan makan Untuk menyelesaikan permasalahan yang ada, penulis melakukan perancangan Sistem Penunjang Keputusan Menggunakan Metode Multi Objective Optimization On The Basis Of Rasio Analysis (MOORA). Aplikasi sistem penujung keputusan ini sangat bermanfaat untuk PT.Naga Hari Utama Medan karena dapat membantu dalam pengambilan keputusan yang lebih cepat, tepat dalam pelihan calon anggota security yang siap kerja.

Untuk merancang sistem sistem penujang keputusan, terlebih dahulu dilakukan pengumpulan data yang akan di implementasikan kedalam sistem yang akan dirancang merupakan data calon anggota security, dan data kriteria serta bobot [9], untuk melakukan perhitungan yang akan menghasilkan nilai dalam perhutungan metode Multi Objective Optimization On The Basis Of Rasio Analysis (MOORA). Langkah langkah perhitungan metode MOORA [10]

\section{Studi Kasus}

a. Tabel kriteria, sub kriteria dan bobot

Tabel 1. Kriteria, Sub Kriteria Dan Bobot

\begin{tabular}{|c|c|c|c|}
\hline Kriteria & Sub Kriteria & Bobot & Keterangan \\
\hline \multirow[t]{6}{*}{ Tinggi Badan } & & $20 \%$ & \\
\hline & $176 \mathrm{~cm}-180 \mathrm{~cm}$ & 5 & Sangat Baik \\
\hline & $166 \mathrm{~cm}-175 \mathrm{~cm}$ & 4 & Baik \\
\hline & $161 \mathrm{~cm}-165 \mathrm{~cm}$ & 3 & Cukup Baik \\
\hline & $156 \mathrm{~cm}-160 \mathrm{~cm}$ & 2 & Kurang Baik \\
\hline & $150 \mathrm{~cm}-155 \mathrm{~cm}$ & 1 & Tidak Baik \\
\hline \multirow[t]{6}{*}{ Berat Badan } & & $20 \%$ & \\
\hline & $71 \mathrm{~kg}-75 \mathrm{~kg}$ & 5 & Sangat Baik \\
\hline & $66 \mathrm{~kg}-70 \mathrm{~kg}$ & 4 & Baik \\
\hline & $61 \mathrm{~kg}-65 \mathrm{~kg}$ & 3 & Cukup Baik \\
\hline & $56 \mathrm{~kg}-60 \mathrm{~kg}$ & 2 & Kurang Baik \\
\hline & $50 \mathrm{~kg}-55 \mathrm{~kg}$ & 1 & Tidak Baik \\
\hline \multirow[t]{2}{*}{ Pengalaman Kerja } & & $15 \%$ & \\
\hline & 4 Tahun & 5 & Sangat Baik \\
\hline
\end{tabular}




\begin{tabular}{|c|c|c|c|}
\hline & 3 Tahun & 4 & Baik \\
\hline & 2 Tahun & 3 & Cukup Baik \\
\hline & 1 Tahun & 2 & Kurang Baik \\
\hline & Belum Berpengalaman & 1 & Tidak Baik \\
\hline \multirow{3}{*}{$\begin{array}{l}\text { pemeriksaan } \\
\text { Kesehatan }\end{array}$} & & $15 \%$ & \\
\hline & Sehat & 5 & Sangat Baik \\
\hline & Tida Sehat & 1 & Tidak Baik \\
\hline \multirow{3}{*}{$\begin{array}{l}\text { Memiliki } \\
\text { Sertifikat }\end{array}$} & & $10 \%$ & \\
\hline & $\mathrm{Ya}$ & 5 & Sangat Baik \\
\hline & Tidak & 1 & Tidak Baik \\
\hline \multirow[t]{5}{*}{ Usia } & & $10 \%$ & \\
\hline & 19 - 25 Tahun & 3 & Cukup Baik \\
\hline & 26 - 30 Tahun & 4 & Baik \\
\hline & 31 - 40 Tahun & 2 & Kurang Baik \\
\hline & 41 - 45 Tahun & 1 & Tidak Baik \\
\hline \multirow[t]{3}{*}{ Teknik Bola Diri } & & $10 \%$ & \\
\hline & 19 - 25 Tahun & 5 & $\mathrm{Ya}$ \\
\hline & $26-30$ Tahun & 4 & Tidak \\
\hline
\end{tabular}

(Sumber : PT.Naga Hari Utama Medan)

b. Tabel Alternatif

Tabel 2. Alternatif

\begin{tabular}{|l|l|}
\hline Alternatif & Nama \\
\hline A1 & Harinal Hakki \\
\hline A2 & Sabarhati \\
\hline A3 & Fazarman Laia \\
\hline A4 & Eldy Irawan \\
\hline A5 & Dicky Hidayat \\
\hline
\end{tabular}

(Sumber : PT.Naga Hari Utama Medan)

1 Contoh Kasus

A. Langkah 1 : (Pemberian Nilai Pada setiap Kriteria)

Tabel 3. Nilai setiap alternatif pada setiap kriteria

\begin{tabular}{|l|l|l|l|l|l|l|l|}
\hline Alternatif & C1 & C2 & C3 & C4 & C5 & C6 & C7 \\
\hline A1 & 3 & 4 & 4 & 5 & 5 & 3 & 5 \\
\hline A2 & 4 & 4 & 1 & 5 & 1 & 3 & 5 \\
\hline A3 & 3 & 3 & 3 & 5 & 1 & 3 & 5 \\
\hline A4 & 4 & 3 & 1 & 5 & 5 & 3 & 5 \\
\hline A5 & 4 & 4 & 2 & 5 & 1 & 3 & 1 \\
\hline
\end{tabular}

(Sumber : PT. Naga Hari Utama Medan)

B. Langkah 2. Mengubah nilai kriteria menjadi matriks keputusan Matriks Keputusan $\mathrm{X}_{\mathrm{ij}}$ 


$$
X=\left\{\begin{array}{ccccccc}
7 & \text { Tabel 4. Matriks Keputusan } X_{\mathrm{ij}} & \\
3 & 3 & 4 & 5 & 5 & 3 & 5 \\
4 & 4 & 1 & 5 & 1 & 3 & 5 \\
3 & 3 & 3 & 5 & 1 & 3 & 5 \\
4 & 3 & 1 & 5 & 5 & 3 & 5 \\
4 & 4 & 2 & 5 & 1 & 3 & 1
\end{array}\right\}
$$

C. Langkah 3. Normalisasi Pada Metode MOORA

Rumus :

$\mathrm{X}_{\mathrm{ij}}^{*}=\mathrm{x}_{\mathrm{ij}} / \sqrt{\sum_{j=1}^{m} x^{2}}{ }_{\mathrm{ij}}$
$\mathrm{C} 1=\sqrt{3^{\wedge}+4^{\wedge}+3^{\wedge}}$

$\mathrm{C} 1=\sqrt{3^{\wedge}+4^{\wedge}+3^{\wedge}+4^{\wedge}+4^{\wedge}}=8.124$

$\mathrm{A}_{11}=3 / 8.124=0.369$

$\mathrm{A}_{21}=4 / 8.124=0.492$

$\mathrm{A}_{31}=3 / 8.124=0,369$

$\mathrm{A}_{41}=4 / 8.124=0,492$

$\mathrm{A}_{51}=4 / 8.124=0,492$

$\mathrm{C} 2=\sqrt{4^{\wedge}+4^{\wedge}+3^{\wedge}+3^{\wedge}+4^{\wedge}}=8.124$

$\mathrm{A}_{12}=4 / 8.124=0,492$

$\mathrm{A}_{22}=4 / 8.124=0,492$

$\mathrm{A}_{32}=3 / 8.124=0,396$

$\mathrm{A}_{42}=3 / 8.124=0,396$

$\mathrm{A}_{52}=4 / 8.124=0,492$

$\mathrm{C} 3=\sqrt{4^{\wedge}+1^{\wedge}+3^{\wedge}+1^{\wedge}+2^{\wedge}}=5.568$

$\mathrm{A}_{13}=4 / 5.568=0,718$

$\mathrm{A}_{23}=1 / 5.568=0,180$

$\mathrm{A}_{33}=3 / 5.568=0,539$

$\mathrm{A}_{43}=1 / 5.568=0,180$

$\mathrm{A}_{53}=2 / 5.568=0,359$

$\mathrm{C} 4=\sqrt{5^{\wedge}+5^{\wedge}+5^{\wedge}+5^{\wedge}+5^{\wedge}}=11.180$

$\mathrm{A}_{14}=5 / 11.180=0.447$

$\mathrm{A}_{24}=5 / 11.180=0.447$

$\mathrm{A}_{34}=5 / 11.180=0.447$

$\mathrm{A}_{44}=5 / 11.180=0.447$

$\mathrm{A}_{54}=5 / 11.180=0.447$

$\mathrm{C} 5=\sqrt{5^{\wedge}+1^{\wedge}+1^{\wedge}+5^{\wedge}+1^{\wedge}}=7.280$

$\mathrm{A}_{15}=5 / 7.280=0,687$

$\mathrm{A}_{25}=1 / 7.280=0,137$

$\mathrm{A}_{35}=1 / 7.280=0,137$

$\mathrm{A}_{45}=5 / 7.280=0,687$

$\mathrm{A}_{55}=1 / 7.280=0,137$

$\mathrm{C} 6=\sqrt{3^{\wedge}+3^{\wedge}+3^{\wedge}+3^{\wedge}+3^{\wedge}}=6.708$

$\mathrm{A}_{16}=3 / 6.708=0,447$

$\mathrm{A}_{26}=3 / 6.708=0,447$

$\mathrm{A}_{36}=3 / 6.708=0,447$

$\mathrm{A}_{46}=3 / 6.708=0,447$

$\mathrm{A}_{56}=3 / 6.708=0,447$ 
$\mathrm{C} 7=\sqrt{5^{\wedge}+5^{\wedge}+5^{\wedge}+5^{\wedge}+1^{\wedge}}=10.050$

$\mathrm{A}_{17}=5 / 10.050=0,498$

$\mathrm{A}_{27}=5 / 10.050=0,498$

$\mathrm{A}_{37}=5 / 10.050=0,498$

$\mathrm{A}_{47}=5 / 10.050=0,498$

$\mathrm{A}_{57}=1 / 10.050=0,498$

Tabel 5. Hasil Perhitungan Normalisasi matrikx $X^{*}{ }_{\text {ij }}$

$\left\{\begin{array}{lllllll}0,369 & 0,492 & 0,718 & 0,447 & 0,687 & 0,447 & 0,498 \\ 0,492 & 0,492 & 0,180 & 0,447 & 0,137 & 0,447 & 0,498 \\ 0,369 & 0,369 & 0,539 & 0,447 & 0,137 & 0,447 & 0,498 \\ 0,492 & 0,369 & 0,180 & 0,447 & 0,689 & 0,447 & 0,498 \\ 0,492 & 0,492 & 0,359 & 0,447 & 0,137 & 0,447 & 0,100\end{array}\right\}$

Tabel 6. Menentukan Nilai $\mathrm{Y}_{\mathrm{i}}$

\begin{tabular}{|l|l|l|l|l|l|l|}
\hline 0,2 & 0,2 & 0,15 & 0,15 & 0,15 & 0,1 & 0,1 \\
\hline 0,369 & 0,492 & 0,718 & 0,447 & 0,687 & 0,447 & 0,498 \\
\hline 0,492 & 0,492 & 0,180 & 0,447 & 0,137 & 0,447 & 0,498 \\
\hline 0,369 & 0,369 & 0,539 & 0,447 & 0,137 & 0,447 & 0,498 \\
\hline 0,492 & 0,369 & 0,180 & 0,447 & 0,689 & 0,447 & 0,498 \\
\hline 0,492 & 0,492 & 0,359 & 0,447 & 0,137 & 0,447 & 0,100 \\
\hline
\end{tabular}

Tabel 7. Hasil Perhitungan Nilai $Y_{i}$

$\left\{\begin{array}{ccccccc}\multicolumn{10}{c}{\text { Tabel 7. Hasil Perhitungan Nilai } Y_{\mathrm{i}}} \\ 0,074 & 0,098 & 0,108 & 0,067 & 0,069 & 0,045 & 0,05 \\ 0,098 & 0,098 & 0,027 & 0,067 & 0,014 & 0,045 & 0,05 \\ 0,074 & 0,074 & 0,081 & 0,067 & 0,014 & 0,045 & 0,05 \\ 0,098 & 0,074 & 0,027 & 0,067 & 0,069 & 0,045 & 0,01 \\ 0,0,98 & 0,098 & 0,054 & 0,067 & 0,014 & 0,045 & 0,01\end{array}\right\}$

D. Langkah ke 4 Mengurangi nilai Maximax dan Minmax

$\mathrm{Y}_{\mathrm{i}}=\sum_{j=1}^{g} w_{\mathrm{j}} \mathrm{X}_{\mathrm{ij}}^{*}-\sum_{j=g+1}^{n} W_{\mathrm{j}} \mathrm{W}_{\mathrm{ij}}^{*}$

Tabel 8. Hasil Persamaan Nilai $Y_{i}$

\begin{tabular}{|l|l|l|l|l|l|l|l|l|}
\hline Kriteria & C1 & C2 & C3 & C4 & C5 & C6 & C7 & Total \\
\hline Harlinal Hakki & 0,074 & 0,098 & 0,108 & 0,067 & 0,069 & 0,045 & 0,05 & 0,511 \\
\hline Sabar Hati & 0,098 & 0,098 & 0,027 & 0,067 & 0,014 & 0,045 & 0,05 & 0,399 \\
\hline Fazarman Laia & 0,074 & 0,074 & 0,081 & 0,067 & 0,014 & 0,045 & 0,05 & 0,405 \\
\hline Eldy Irawan & 0,098 & 0,074 & 0,027 & 0,067 & 0,069 & 0,045 & 0,05 & 0,43 \\
\hline Dicky Hidayat & 0,098 & 0,098 & 0,054 & 0,067 & 0,014 & 0,045 & 0,01 & 0,386 \\
\hline
\end{tabular}


Tabel 9. Hasil Persamaan Niali $Y_{i}$ Sebelum di Rangking

\begin{tabular}{|l|l|}
\hline kriteria & total nilai \\
\hline Harlinal Hakki & 0,511 \\
\hline Sabar Hati & 0,399 \\
\hline Fazarman Laia & 0,405 \\
\hline Eldy Irawan & 0,43 \\
\hline Dicky Hidayat & 0,386 \\
\hline
\end{tabular}

Tabel 10. Hasil Persamaan Nilai $Y_{i}$ Setelah di Rangking

\begin{tabular}{|l|l|l|}
\hline Alternatif & total nilai & keterangan \\
\hline Harlinal Hakki & 0,532 & lolos \\
\hline Eldy Irawan & 0,430 & gagal \\
\hline Fazarman Laia & 0,422 & gagal \\
\hline Sabar Hati & 0,419 & gagal \\
\hline Dicky Hidayat & 0,400 & gagal \\
\hline
\end{tabular}

\subsection{Tampilan Hasil}

a. Tampilan Utama

Tampilan Utama Merupakan Rancangan tampilan awal dalam program dapat di lihat pda gambar berikut :

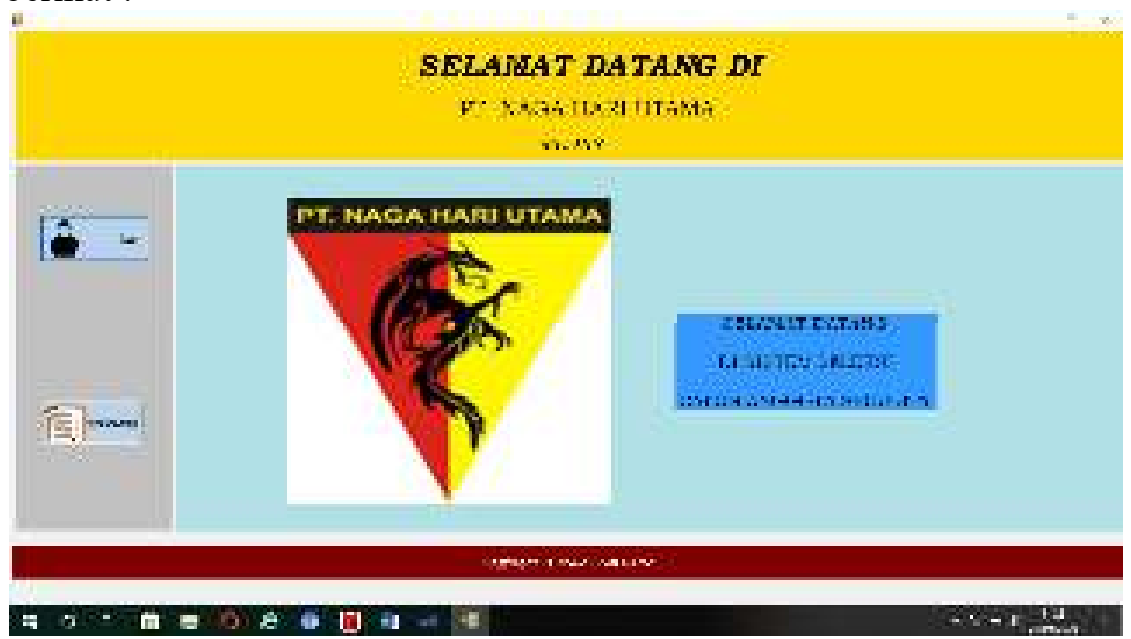

Gambar 1. Tampilan Utama

b. Tampilan Menu Login

Tampilan perancangan menu login dapat di lihat pada gambar berikut : 


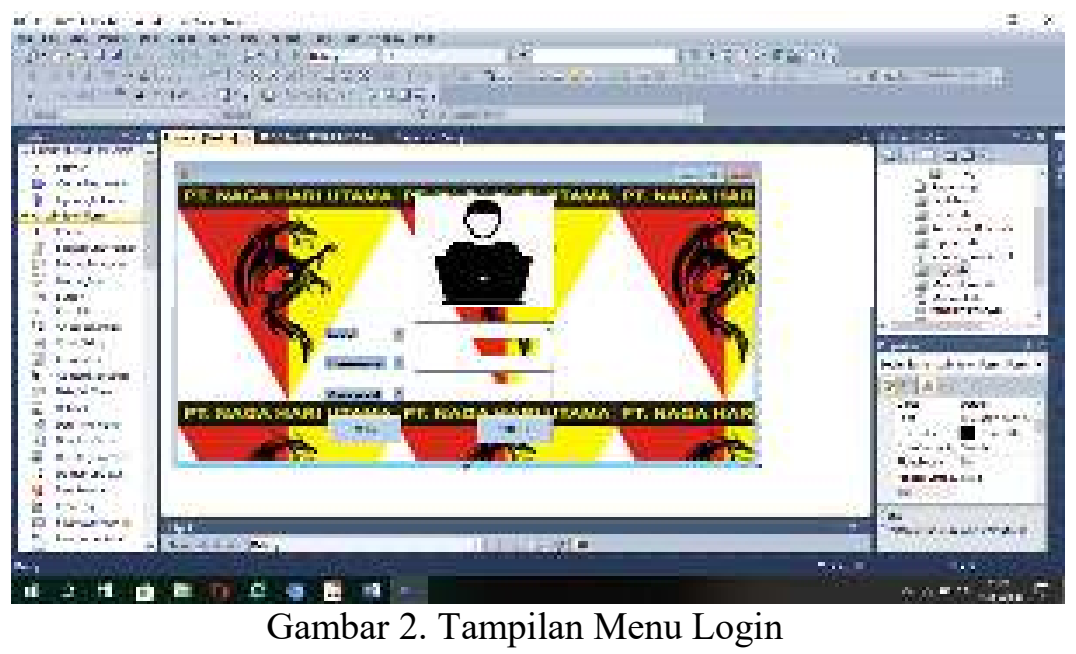

c. Tampilan Menu Utama

Tampilan halaman List data basis aturan berfungsi untuk Administrator melihat daftar basis aturan yang telah diinput didalam sistem.

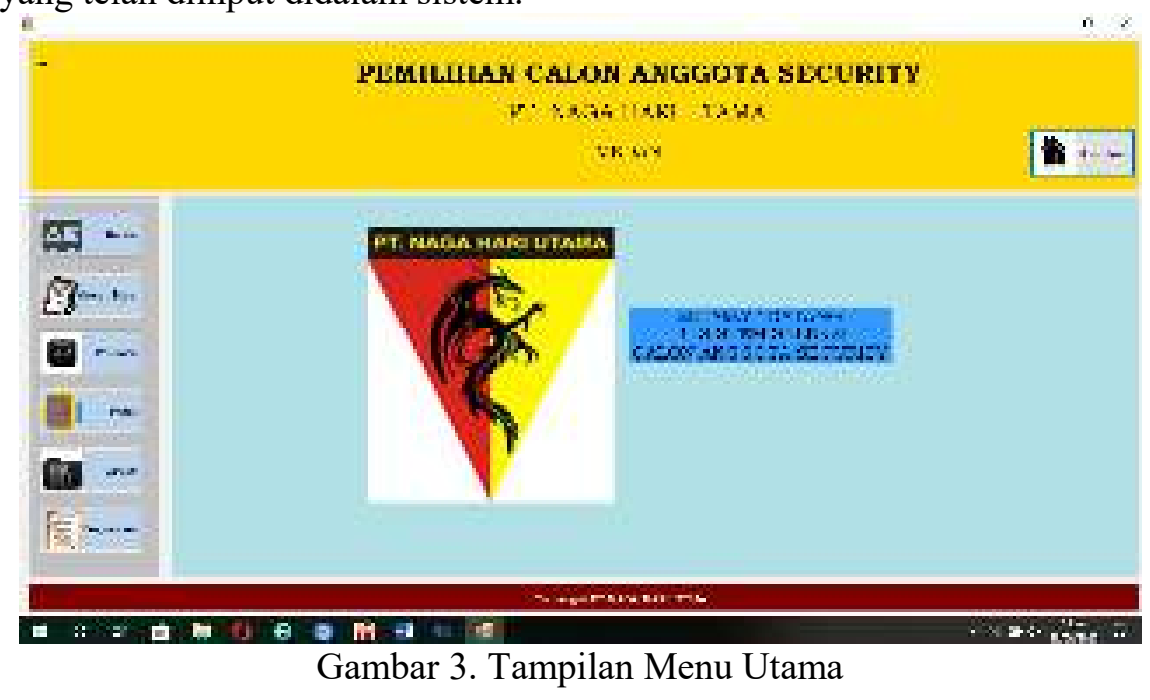

d. Tampilan Menu Biodata

Tampilan rancangan Menu Biodata dapat dilihat pada gambar berikut :

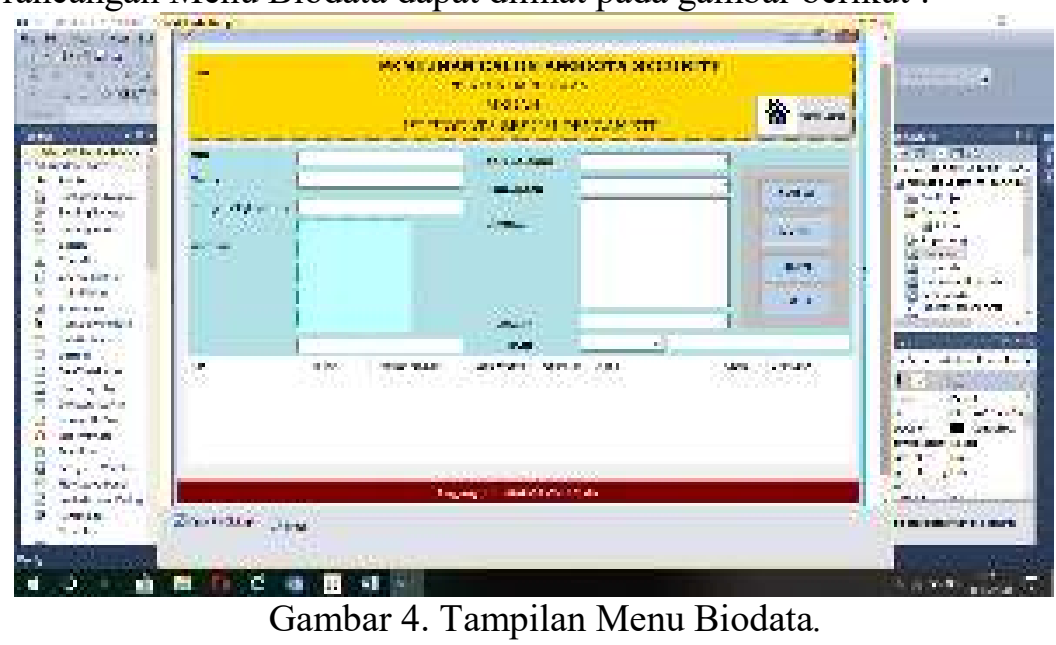

e. Tampilan Menu Kriteria dan Bobot

Perancangan tampilan menu kriteria dan bobot dapat di lihat pada gambar berikut : 


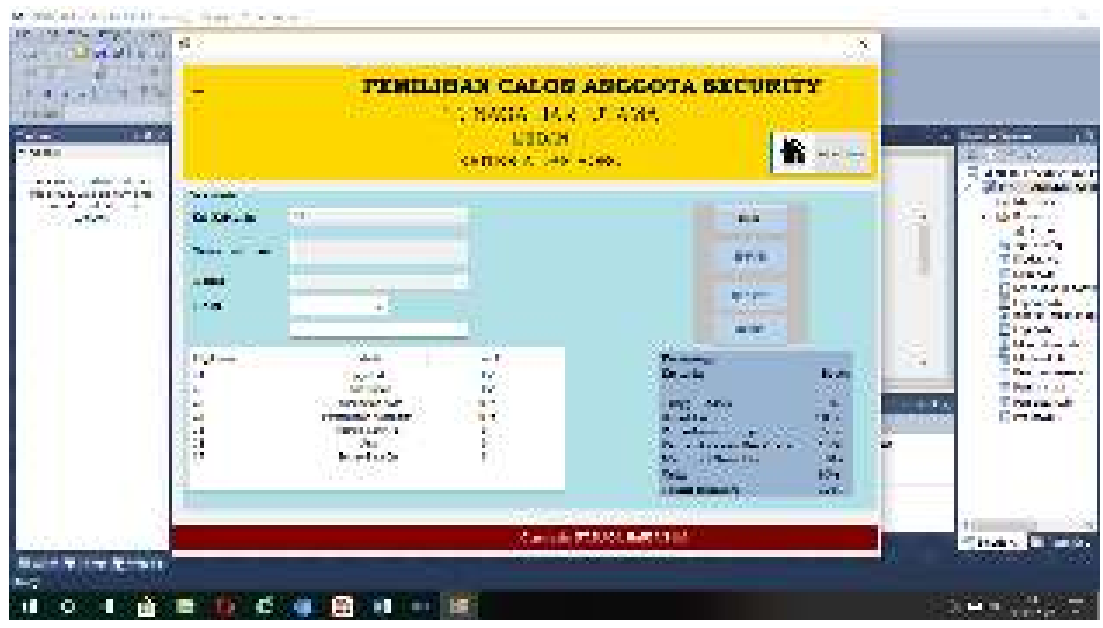

Gambar 5. Tampilan Menu Kriteria dan Bobot

f. Tampilan Menu Penilaian

Rancangan Tampilan Menu Penilaian dapat di lihat sebagai pada gambar berikut :

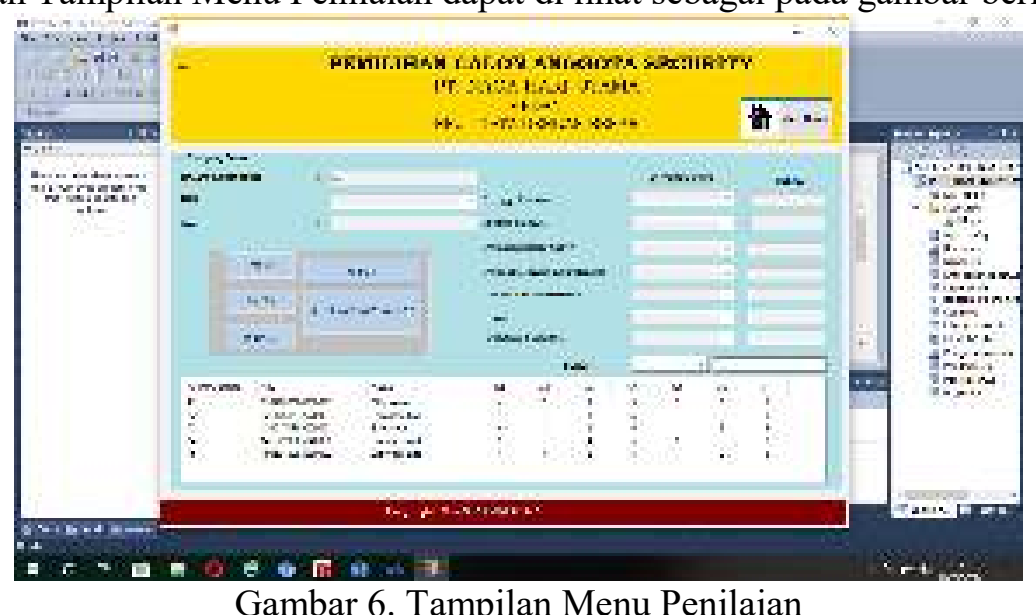

g. Tampilan Menu Proses

Rancangan tampilan menu proses dapat dilihat pada gambar berikut :

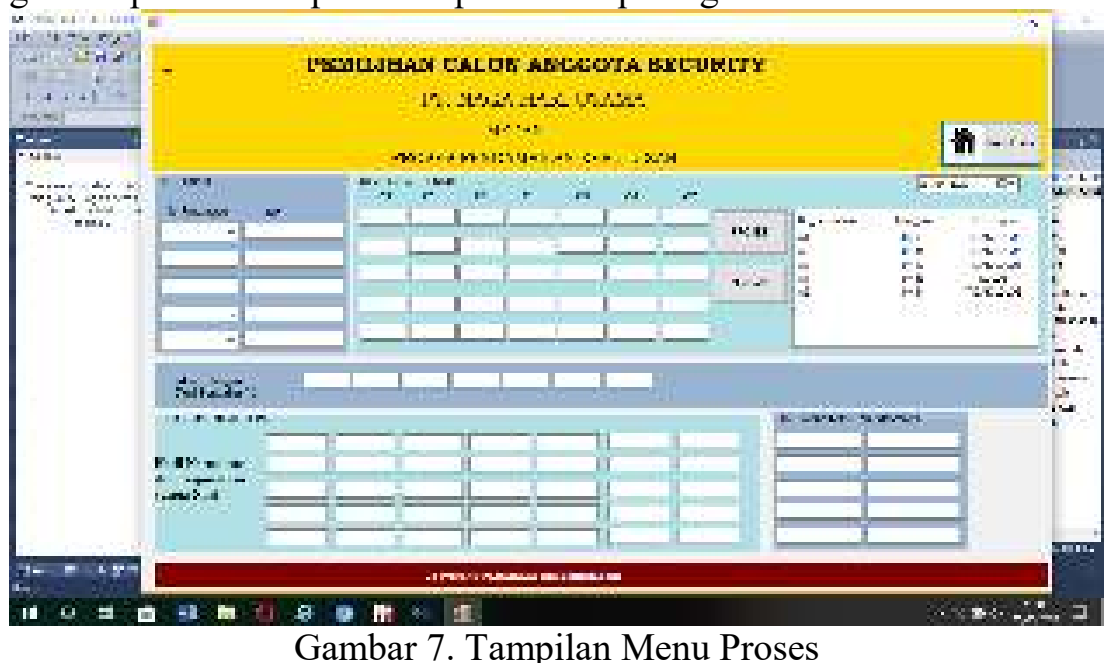

h. Tampilan Menu Laporan

Rancangan Tampilan Menu Laporan dapat di lihat pada gambar berikut : 


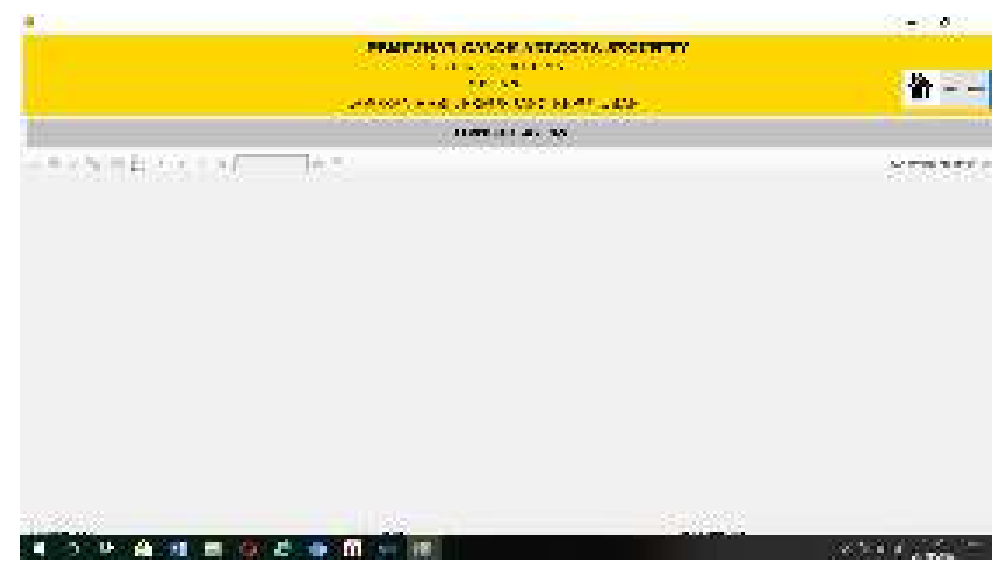

i. Tampilan Menu Pengumuman

Gambar 8. Tampilan Menu Laporan

Rancangan Tampilan Menu Pengumuman dapat di lihat pada gambar berikut :

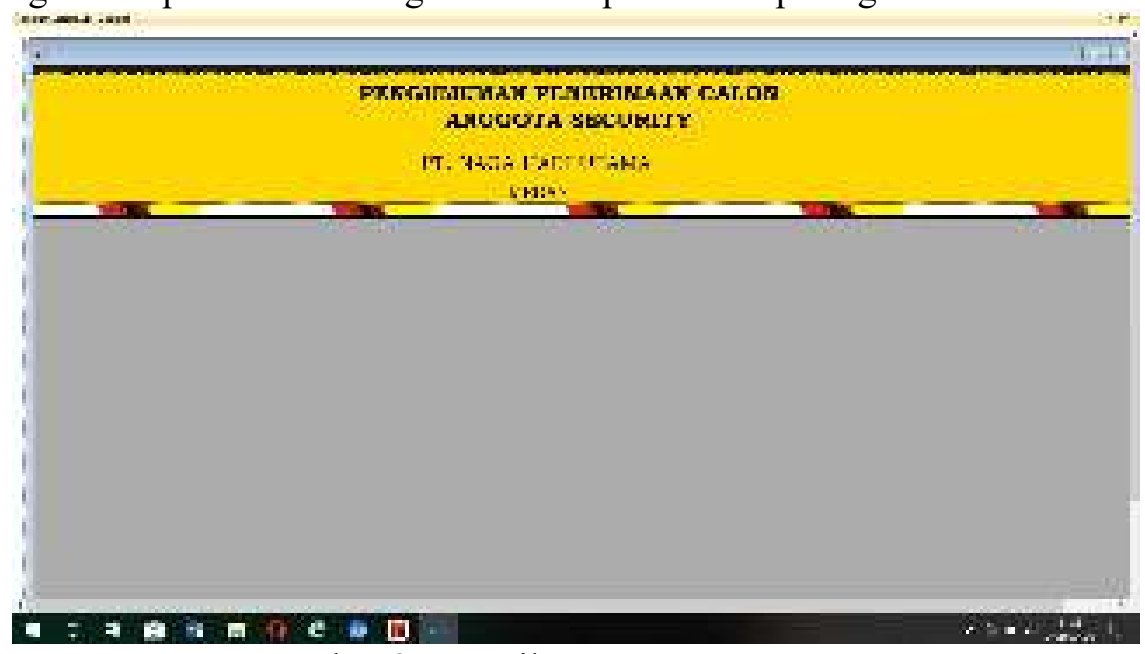

Gambar 9. Tampilan Menu Pengumuman yaitu :

Setelah melakukan uji coba terhadap sistem, maka dapat disimpulkan hasil yang didapatkan

1. Penerapan metode ke dalam sistem telah sesuai dengan perhitungan manual.

2. Sistem yang diterapkan sesuai dengan yang dirancang.

3. Proses keputusan telah sesuai dengan proses manual.

4. Interface bersifat userfriendly sehingga siapa saja dapat menggunakan dengan mudah.

Dalam hasil pengujian sebuah program yang berjalan tidak terlepas dari kekurangan dan kelibihan yang di dapat setelah uji coba di lakukan adapun kekurangan dan kelebihan program. Adapun kekurangan sistem yang telah dibuat diantaranya yaitu :

1. Sistem yang telah di buat tidak memiliki petunjuk penggunaan.

2. Sistem yang telah di buat belum diterapkan berbasis online.

3. Sistem yang telah di buat belum diterapkan pada perangkat mobile.

Adapun kelebihan sistem yang telah dibuat diantaranya yaitu :

1. Program Di rancang dapat menyimpan data setiap Calon Anggota Security.

2. Program Di rancang dapat Memberikan solusi pengambilan keputusan calon anggota security dengan metode yang di terapkan.

3. Penerapan sebuah pengambilan kepurusan dapat di gunakan sesuai dengan masalah yang ditemukan. 


\section{KESIMPULAN}

Sistem Penunjang Keputusan di Rancangan dengan menggunakan bahasa pemograman Visual Basic 2010 dan SQL Server 2008 sebagai Database sebagai sistem yang akan terkomputerisasi. Dengan menggunakan metode MOORA (Metode Multi Objective Optimization On The Basis Of Rasio Analysis) dalam penentuan calon anggota security dengan menerapkan penggunaan kriteria dan bobot sebagai yang telah ada. Proses pengolaha data calon anggota security sebelum nya pada PT. Naga Hari Utama dengan mengunakan proses manual yang sederhana tanpa adanya prses penilaian yang terkomputerrisasi, oleh sebab itu maka dengan penelitian ini diharapkan pengolahan data di lakukan dengan berbasis komputer yang mana dalam proses ini menggunkan metode Metode Multi Objective Optimization on the basis of rasio analysis (MOORA) sebagai pengolahan nilai kriteria dan bobot sebagai proses pengambilan keputusan. Proses perhitungan dalam moora memiliki beberapa tahapan yang pertama menentukan nilai setiap kriteria. Lalu mengubah nilai kriteria menjadi matriks keputusan setelah di tentukan nilai nya maka nilai akan di normalisasi pada metode moora lalu setelah di temukan nilai hasil normalisasi maka di lakukan mengurangi nilai Maximax dan Minimax untuk membedakan atribut lebih penting jika memiliki bobot yang lebih peting jika tidak maka masuk ke langkah yang terakhir yaitu menentukan rangkin pada setiap alternatif dengan ketentuan yang telah di buat yaitu jika nilai total $<=0.5$ maka lulus atau jika nilai total $<=1$ maka dikatakan lulus jika tidak maka akan dikatakan tidak lolos, maka setelah semua selesai seluruh data akan di simpan di komputer

\section{SARAN} berikut :

Adapun saran yang diberikan penulis dalam dalam penulisan Tugas akhir ini adalah sebagai

1. Dengan penerapan metode MOORA untuk pengembangannya sebaiknya semakin di sesuaikan dengan metode yang berkembang atau perpaduan dua metode yang cocok dengan masalah pelihan calon anggota security.

2. Penerapan sistem yang di rancang sebaiknya lebih interaktif dan mengikuti perkembangan dan pengembangan sistem terbaru seperti sistem online.

3. Sebaiknya Pengembang semakin menyesuai kan penggunaan bahasa pemograman yang berkembang seperti Java, Android, guna lebih interaktif dengan keadaan yang akan datang.

\section{UCAPAN TERIMA KASIH}

Penulis mengucapkan terima kasih kepada Universitas Potensi Utama yang telah banyak memberikan masukkan dan saran dalam penyelesaian penelitian ini.

\section{DAFTAR PUSTAKA}

[1] Wibowo, A. P., \& Hartati, S. (2016). Sistem Klasifikasi Kinerja Satpam Menggunakan Metode Naïve Bayes Classifier. INOVTEK Polbeng-Seri Informatika, 1(2), 192-201.

[2] Alfina, O., \& Harahap, F. (2019, September). Implementasi Metode Topsis Dalam Penentuan Kelas Siswa Tunagrahita. In Prosiding Seminar Nasional Riset Information Science (SENARIS) (Vol. 1, pp. 191-200).

[3] Sianturi, J. (2019). SISTEM PENDUKUNG KEPUTUSAN PEMILIHAN ANGGOTA POLRI TERBAIK DENGAN MENERAP KAN METODE MOORA (MULTI OBJECTIVE OPTIMIZATION ON THE BASIS OF RASIO ANALYSIS)(STUDI KASUS: POLRES DELI SERDANG). Pelita Informatika: Informasi dan Informatika, 8(1), 19-25.

[4] [Revi, A., Parlina, I., \& Wardani, S. (2018). Analisis Perhitungan Metode MOORA dalam Pemilihan Supplier Bahan Bangunan di Toko Megah Gracindo Jaya. InfoTekJar: Jurnal Nasional Informatika dan Teknologi Jaringan, 3(1), 95-99. 
[5] Safii, M., \& Zulhamsyah, A. (2018). Sistem Pendukung Keputusan Pemilihan Mekanik Sepeda Motor Yamaha Alfascorfii Dengan Metode Multi Objective Optimization On The Basis Of Ratio Analysis (MOORA). J-SAKTI (Jurnal Sains Komputer dan Informatika), 2(2), 162-168.

[6] Alfina, O., \& Harahap, F. (2019). PEMODELAN UML SISTEM PENDUKUNG KEPUTUSAN DALAM PENENTUAN KELAS SISWA SISWA TUNAGRAHITA. METHOMIKA: Jurnal Manajemen Informatika \& Komputerisasi Akuntansi, 3(2), 143-150.

[7] Sasmito, G. W. (2017). Penerapan Metode Waterfall Pada Desain Sistem Informasi Geografis Industri Kabupaten Tegal. Jurnal Informatika: Jurnal Pengembangan IT, 2(1), 6-12.

[8] Kristanto, I. H. (1994). Konsep \& Perancangan Database. Penerbit Andi.

[9] Haryanto, H. (2018). PEMBUATAN APLIKASI SISTEM PENUNJANG KEPUTUSAN UNTUK PEMILIHAN PENERIMA BEASISWA SISWA KMS DENGAN METODE MOORA. Jurnal Informa, 4(1), 15-19.

[10] Olivianita, L., Ekojono, E., \& Ariyanto, R. (2016, November). Sistem pendukung keputusan kelayakan hasil cetakan buku menggunakan metode moora. In Seminar Informatika Aplikatif Polinema. 